\title{
Norsified English or Anglicized Norse?
}

\author{
Peter Trudgill \\ University of Agder \\ peter.trudgill@unifr.ch
}

\begin{abstract}
Emonds \& Faarlund have brilliantly demonstrated that the syntax of English owes a great deal to the syntax of Old Norse, and more than has generally been thought. This is genuinely significant. But, from a variationist perspective, the difference of nomenclature- "North Germanic" rather than "West Germanic"—is not.
\end{abstract}

\section{Keywords}

historical syntax - language contact - history of English - Germanic

Emonds and Faarlund have shown very powerfully and elegantly that the language I am now writing in is not descended in any uncomplicated kind of way from the Old English of Wessex. It is clearly the result of contact between the $\mathrm{OE}$ of parts of Britain other than Wessex, and Old Norse (ON). The language on this page is the direct descendant-albeit with large amounts of lexis from AngloNorman, French, Latin, Ancient Greek — of a linguistic variety which had many of its origins in the Scandinavian north, midlands and east of England. ${ }^{1}$

Thomason and Kaufman (1988) called this variety "Norsified English." Emonds and Faarlund prefer to call it "Anglicized Norse." They find the difference in terminology significant. I am not persuaded.

I genuinely am persuaded that Emonds and Faarlund have brilliantly demonstrated that the syntax of my native language owes a great deal to the syntax of ON-and very much more than has generally been thought. That is

1 I would also want to argue for the role of contact with Late Brittonic Celtic (see Trudgill, 2010). 
truly highly significant. But, from a variationist perspective, the difference of nomenclature is not.

Variationists can agree with Emonds and Faarlund that this language is incontrovertibly the result of contact and mixture. And we can agree that it shows signs of contact-induced simplification. This would make it a creoloid, if the contact was language contact; or a koiné, if it was dialect contact. Which of the two it is, of course, is a question with no clearcut answer. The difference between the two is a matter of more or less (Trudgill, 2000). Mutual intelligibility, if this is our defining characteristic, is not a matter of either-or but of degree - a continuum. (For a helpful discussion of ON-OE intelligibility, see Townend, 2005.)

Emonds and Faarlund, however, do not seem happy with continua or clines. In their book, there are a few-as it seems to me-gratuitous references to "Universal Grammar." This signals to sociolinguists, dialectologists and variationists that Emonds and Faarlund are working with a generativist mindset which we, rightly or wrongly, feel leads to an approach which can be characterized as thinking in boxes. Everything is perceived in terms of discrete categories. There is little room for the continua, gradience and variability which are a central part of our work.

This mindset has the unfortunate consequence of diverting attention from Emonds and Faarlund's deeply impressive achievement. They have concluded not just that English has been profoundly influenced by on syntax, but also that it belongs on the North Germanic branch of the Germanic family tree, not the West Germanic: English, they say, is North Germanic. But as was noted long ago by Schmidt (1872) and Schuchardt (1868), the family tree model is a fiction. It can often be helpful, but it can also obscure:Versteegh (2014:14) writes of the genetic classification of the Semitic languages that "the genealogical paradigm ... has been severely criticised ... because of its incompatibility with the nature of the linguistic situation." The question 'is English North Germanic or West Germanic?' does not have to be a meaningful one. There is clearly much originally North Germanic material in English-especially, as we now understand, syntactic material. But to deny that it also has West Germanic antecedents would be misguided.

To ask if Middle English was Anglicized Norse or Norsified English is not, from a sociolinguistic perspective, very helpful. Robert Le Page's (1985) important work taught us long ago that languages can be more or less focused or diffuse. Diffuse linguistic communities are those where little codification has taken place; there is relatively little agreement about norms; speakers show little concern for demarcating their language variety from others; and they may accord relatively little importance even to what their language is called. 
Focused communities are those where codification has taken place; there is a high degree of agreement about norms; speakers tend to show concern for 'purity' and demarcating their language variety from others; and everyone agrees about the language's name. Le Page points out that notions like language mixing, code-switching, and "borrowing" depend on a focused-languagecentered view of the separate status of language varieties.

Things were not like that in Viking Age England, as Emonds and Faarlund agree. No one then would have perceived the sociolinguistic situation as being one of bilingualism, because they had no perception that two separate languages were involved. But, as Emonds and Faarlund do not agree, there is no reason for us to have that perception either. It is not a matter of "alternatives"of either North Germanic or West Germanic. This language of mine really is descended from the language of the Vikings; but it is also descended from the Anglo-Saxon dialects of Wessex, Northumbria and, especially, Mercia.

\section{References}

Le Page, Robert B. and Andrée Tabouret-Keller. 1985. Acts of Identity: Creole-based Approaches to Language and Ethnicity. Cambridge: Cambridge University Press.

Schmidt, Johannes. 1872. Die Verwandtschaftsverhältnisse der indogermanischen Sprachen. Weimar: Bohlau.

Schuchardt, Hugo. 1868. Der Vokalismus des Vulgärlateins. Leipzig: Teubner.

Thomason, Sarah Grey and Terrence Kaufman. 1988. Language Contact, Creolization, and Genetic Linguistics. Berkeley, CA: University of California Press.

Townend, Matthew. 2005. Language and History in Viking Age England: Linguistic Relations between Speakers of Old Norse and Old English. Turnhout: Brepols.

Trudgill, Peter. 2000. On locating the boundary between language contact and dialect contact: Low German and continental Scandinavian. In Ernst Håkon Jahr (ed.), Språkkontakt: innverknaden frå nedertysk på andre nordeuropeiske språk, 71-86. Copenhagen: Nordisk Ministerråd.

Trudgill, Peter. 2010. Investigations in Sociohistorical Linguistics: Stories of Colonisation and Contact. Cambridge: Cambridge University Press.

Versteegh, Kees. 2014. The Arabic Language. Edinburgh: Edinburgh University Press. 